\title{
Kompetensi Fasilitator Pelatihan Pusat Pengembangan dan Pemberdayaan Pendidik dan Tenaga Kependidikan Pertanian (P4TK Pertanian), Kementerian Pendidikan dan Kebudayaan
}

\section{Competency of Training Facilitator Center for Empowering and Developing Educators and Educational Personnels Agriculture, Ministry of Education and Culture}

\author{
Eko Warisdiono $^{1}$, Ma'mun Sarma ${ }^{1}$, Darwis S. Gani, Djoko Susanto ${ }^{2}$ \\ ${ }^{1}$ Program Studi Ilmu Penyuluhan Pembangunan, Institut Pertanian Bogor, Bogor \\ ${ }^{2}$ Pusat Penelitian dan Pengembangan Gizi, Departemen Kesehatan RI, Jakarta
}

\begin{abstract}
The success of the training execution one other is determined by facilitator competency. Therefore facilitator is strived to have competency in implementing learning task suitable with the wish and need of training participants. The aims of this research is to analyse factors dominantly influencing competency of facilitators of P4TK Pertanian Cianjur. This research is conducted in P4TK Pertanian Cianjur, using P4TK fasilitators as respondents. The research is carried out in P4TK Pertanian Cianjur using 121 facilitators by census. Reserch result showed that most part of the facilitators master the competence in the level of medium. Factors that significantly influencing positively the competence of the facilitators are involvement of facilitators in learning process, motivation, and working environment. Meanwhile the individual characteristics does not significantly influence facilitator competency.
\end{abstract}

Keywords: training, facilitator, competency

\begin{abstract}
Abstrak
Keberhasilan pelaksanaan pelatihan yang lain ditentukan oleh kompetensi fasilitator. Oleh karena itu fasilitator diupayakan memiliki kompetensi dalam melaksanakan tugas belajar yang sesuai dengan keinginan dan kebutuhan peserta pelatihan. Tujuan dari penelitian ini adalah untuk menganalisis faktor-faktor dominan yang mempengaruhi kompetensi fasilitator P4TK Pertanian Cianjur. Penelitian ini dilakukan di P4TK Pertanian Cianjur, menggunakan fasilitator P4TK sebagai responden. Penelitian ini dilakukan di P4TK Pertanian Cianjur menggunakan 121 fasilitator dengan cara sensus. Hasil riset menunjukkan bahwa sebagian besar dari para fasilitator menguasai kompetensi di tingkat menengah. Faktor-faktor yang secara signifikan mempengaruhi kompetensi fasilitator adalah keterlibatan fasilitator dalam proses belajar, motivasi, dan lingkungan kerja. Sementara itu karakteristik individu tidak berpengaruh signifikan terhadap kompetensi fasilitator.
\end{abstract}

Kata kunci: pelatihan, fasilitator, kompetensi

\section{Pendahuluan}

Pelatihan merupakan salah satu bentuk penyuluhan guna menyiapkan masyarakat agar tahu, mau dan mampu untuk menguasai kompetensi tertentu sehingga menjadi lebih berdaya dan meningkat kesejahteraannya.Pemberdayaanyang dilakukanmelalui pelatihan bertujuan untuk memperkuat posisi seseorang melalui penumbuhan kesadaran dan kemampuan individu yang bersangkutan, mengidentifikasi persoalan yang dihadapi dan memikirkan langkah-langkah untuk mengatasinya.

Salah satu komponen dari kegiatan pelatihan yang mempunyai peranan penting dalam keberhasilan pelatihan adalah keberadaan fasilitator. Kesuksesan suatu program diklat sangat ditentukan oleh tingkat profesionalisme yang dimiliki oleh fasilitator. Fasilitator yang profesionalmemilikikompetensiataukemampuan mengajar dan kemampuan memfasilitasi yang unggul dalam suatu proses pembelajaran/pelatihan. Fasilitator yang kompeten mampu menciptakan lingkungan belajar yang kondusif dan efektif serta mampu mengelola kelas dan membawa peserta pelatihan mencapai hasil belajar yang optimal. Kompetensi fasilitator sangat penting bagi penyelenggara pelatihan untuk menjamin mutu pelaksanaan pelatihan sesuai dengan harapan dan kebutuhan peserta. Mendukung pelaksanaan tugas fasilitator, P4TK Pertanian telah melakukan berbagai kegiatan peningkatan kompetensi fasilitator baik melalui peningkatan pendidikan formal 
maupun pelatihan, magang, seminar, workshop, praktek lapangan, penelitian dan penulisan karya ilmiah. Namun demikian pada kenyataannya program peningkatan kompetensi tersebut belum dapat diketahui manfaatnya dalam memenuhi kebutuhan kompetensi fasilitator. Oleh karena itu tingkat kompetensi dan faktor-faktor yang mempengaruhi kompetensi fasilitator perlu diketahui sebagai bagian dari upaya pengembangan kompetensi fasilitator.

Pelatihan menurut Malthis dan Jackson (2002), adalah suatu proses dimana orang-orang mencapai kemampuan tertentu untuk membantu mencapai tujuan organisasi. Pelatihan merupakan sebuah proses sistematis untuk mengubah perilaku kerja seorang/sekelompok orang dalam usaha meningkatkan kinerja organisasi. Pelatihan berkaitan dengan keterampilan dan kemampuan yang diperlukan untuk pekerjaanyang sekarang dilakukan. Selanjutnya Jacius (Moekijat, 1990) mengemukakan bahwa istilah pelatihan menunjukkan suatu proses peningkatan sikap, kemampuan, dan kecakapan dari para pekerja untuk menyelenggarakan pekerjaan secara khusus. Pernyataan tersebutmenunjukkan bahwa kegiatan pelatihan merupakan proses membantu peserta untuk memperoleh keefektifan dalam melakukan pekerjaan mereka baik pada saat sekarang maupun masa yang akan datang melalui pengembangan kebiasaan pikiran dan tindakan-tindakan, kecakapan, pengetahuan, dan sikapsikap.

Pelatihan menurut Pasal 26 Undang-Undang Nomor 20 Tahun 2003 tentang Sistem Pendidikan Nasional, termasuk dalam jalur pendidikan nonformal yaitu jalur pendidikan di luar pendidikan formal yang dapat dilaksanakan secara terstruktur dan berjenjang. Pendidikan nonformal diselenggarakan bagi warga masyarakat yang memerlukan layanan pendidikan yang berfungsi sebagai pengganti, penambah, dan/ atau pelengkap pendidikan formal dalam rangka mendukung pendidikan sepanjang hayat. Pendidikan non-formal berfungsi mengembangkan potensi peserta didik dengan penekanan pada penguasaan pengetahuan dan keterampilan fungsional serta pengembangan sikap dan kepribadian profesional.

Komponen-komponen dalam pelaksanaan pelatihan menurut Mangkunegara (2005) terdiri atas: (1) tujuan dan sasaran pelatihan dan pengembangan harus jelas dan dapat di ukur; (2) para pelatih (trainer) harus ahlinya yang berkualitas memadai (profesional); (3) materi pelatihan dan pengembangan harus disesuaikan dengan tujuan yang hendak dicapai; dan
(4) peserta pelatihan harus memenuhi persyaratan yang ditentukan. Dari keempat komponen pelatihan tersebut, pelatih (trainer) mempunyai peran penting dalam keberhasilan pelatihan. Pelatih (trainet) sebagai salah satu komponen pelatihan sering disebut dengan istilah yang berbeda-beda seperti instruktur, pengajar, tutor dan perkembangan terakhir banyak digunakan istilah fasilitator.

Fasilitator dalam Undang-Undang Nomor 20 Tahun 2003 tentang Sistem Pendidikan Nasional merupakan salah satu kualifikasi pendidik disamping guru, dosen, konselor, pamong belajar, widyaiswara, tutor, instruktur atau sebutan lainnya sesuai dengan kekhususannya. Pendidik merupakan tenaga profesional yang bertugas merencanakan dan melaksanakan proses pembelajaran, menilai hasil pembelajaran, melakukan pembimbingan dan pelatihan, serta melakukan penelitian dan pengabdian kepada masyarakat, terutama bagi pendidik pada perguruan tinggi. Fasilitator pelatihan dalam penelitian ini adalah pendidik pada kegiatan pelatihan yang bertugas merencanakan pembelajaran, melaksanakan proses pembelajaran, menilai hasil pembelajaran, melakukan pembimbingan dan pelatihan. Istilah fasilitator sebagai pendidik banyak digunakan dalam pendidikan non-formal terutama pada kegiatan pelatihan baik yang diselenggarakan oleh lembaga diklat pemerintah maupun non pemerintah.

Peran fasilitator pelatihan pada kegiatan pelatihan sebagai tenaga pendidik menurut menurut Roestiyah (2001) adalah: (1) sebagai pelatih, fasilitator membantu peserta pelatihan belajar membuat kesepakatan dan rencana belajar, mengamati peserta dalam melaksanakan rencana belajar, menawarkan saran, melakukan demonstrasi, membantu peserta mengidentifikasi kebutuhan materi belajar, memonitor kemajuan peserta, menyarankan pendekatan baru yang diperlukan, dan membantu peserta pelatihan; (2) sebagai pemandu, fasilitator menunjukkan peserta arah yang tepat dalam belajar dan membantu menetapkan ke tujuan belajarnya; (3) sebagai desainer lingkungan belajar, fasilitator membantu peserta pelatihan untuk membangun suatu lingkungan belajar sesuai dengan kebutuhan peserta; (4) fasilitator juga berfungsi sebagai model atau mentor; (5) sebagai evaluator, fasilitator memberikan informasi kepada peserta tentang tujuan pelatihan dan kemajuan belajar mereka.

Agar dapat menjalankan perannya maka fasilitator harus menguasai kompetensi sesuai dengan bidang keahliannya. Kompetensi menurut Mc Clleland 
(1973) adalah karakteristik dasar individu sebagai faktor-faktor yang menentukan keberhasilan dalam suatu pekerjaan atau situasi. Menurut Boyatzis (1982) kompetensi menunjukan kemampuan. Seseorang yang mempunyai seperangkat kompetensi menunjukkan kemampuan atau pekerjaannya. Kompetensi dapat berupa motif, sifat, keterampilan, aspek citra diri atau peran sosial seseorang, atau pengetahuan yang digunakan dan dimiliki dan karakteristik ini mungkin diketahui atau tidak diketahui oleh yang bersangkutan. Spencer dan Spencer(1993), mendefinisikan kompetensi sebagai karakteristik dasar seseorang berkaitan dengan efektivitas kinerja individu dalam pekerjaannya.

Mengacu pada definisi-definisi kompetensi tersebut di atas, definisi kompetensi oleh Spencer dan Spencer (1993) yang berorientasi pada karakteristik personal pada individu yang menimbulkan perilaku yang kompeten, akan digunakan untuk mendalami berbagai aspek yang terkait dalam penelitian ini. Namun demikian definisi kompetensi menurut Spencer dan Spencer (1993) tersebut diadaptasi dengan lingkungan kerja mengacu pada pendapat Boyatzis (1982) bahwa ada pengaruh kompetensi individu dengan lingkungan kerja. Selanjutnya sejalan dengan Boyatzis, Moehariono (2009) menyatakan bahwa kompetensi seseorang dapat dipengaruhi oleh faktor internal maupun eksternal, antara lain: (1) bakat bawaan, (2) motivasi kerja,(3) sikap, motif dan cara pandang, (4) pengetahuan, (5) keterampilan, dan (6) lingkungan kehidupan sehari-hari. Faktor yang berpengaruh dalam penelitian ini difokuskan kepada karakteristik individu, keterlibatan fasilitator dalam proses belajar, lingkungan kerja fasilitator, dan motivasi fasilitator.

Fasilitator mampu melaksanakan tugas pembelajaran jika mempunyai kompetensi yang memadai sesuai dengan materiyang diajarkan meliputi seperangkat pengetahuan, keterampilan, dan perilaku yang harus dimiliki, dihayati, dan dikuasai oleh fasilitator dalam melaksanakan tugas keprofesionalan. Tugas keprofesionalan fasilitator adalah mendidik, mengajar dan melatih peserta pelatihan. Kompetensi yang harus dimiliki oleh fasilitator meliputi kompetensi (1) pengelolaan pembelajaran, (2) kepribadian, (3) sosial, dan (4) substantif. Kompetensi dalam pengelolaan pembelajaran adalah kemampuan dalam merencanakan, menyusun, melaksanakan, dan mengevaluasi pembelajaran. Kompetensi kepribadian adalah kemampuan mengenai tingkah laku dalam melaksanakan tugas jabat-annya yang dapat diamati dan dijadikan teladan bagi peserta pelatihan. Kompetensi sosial adalah kemampuan dalam melakukan hubungan dengan lingkungan kerjanya. Kompetensi substantif adalah kemampuan di bidang keilmuan dan keterampilan dalam mata diklat yang diajarkan. Kompetensi fasilitator dalam penelitian ini meliputi: (1) penguasaan substansi materi; (2) perencanaan pembelajaran; (3) pelaksanaan pembelajaran; (4) evaluasi pembelajaran; dan (5) kerjasama.

Berdasarkan latar belakang pemikiran tersebut, permasalahan utama penelitian ini adalah: (1) bagaimana karakteristik, keterlibatan fasilitator dalam proses belajar, lingkungan kerja, motivasi fasilitator, dan kompetensi fasilitator P4TK Pertanian? (2) faktor apa yang berpengaruh nyata terhadap kompetensi fasilitator P4TK Pertanian? dan (3) bagaimana strategi pengembangan kompetensi fasilitator P4TK Pertanian? Berdasarkan pada permasalahan tersebut di atas maka tujuan penelitian ini adalah: (1) mendeskripsikan karakteristik fasilitator, keterlibatan fasilitator dalam proses belajar, lingkungan kerja fasilitator, motivasi fasilitator, dan kompetensi fasilitator; (2) menganalisis faktor yang berpengaruh nyata terhadap kompetensi fasilitator; dan (3) merumuskan strategi pengembangan kompetensi fasilitator P4TK Pertanian.

\section{Metode Penelitian}

\section{Rancangan Penelitian}

Rancangan penelitian ini adalah explanatory research, yaitu penelitian yang bertujuan untuk menjelaskan hubungan dan pengaruh antar peubahpeubah penelitian melalui pengujian hipotesis. Peubah dalam penelitian ini adalah: karakteristik fasilitator (X1), keterlibatan fasilitator dalam proses belajar (X2), lingkungan kerja fasilitator (X3), motivasi fasilitator (X4), dan kompetensi fasilitator (Y1).

\section{Populasi dan Sampel}

Populasi penelitian ini adalah fasilitator P4TK Pertanian Cianjur sebanyak 121 orang. Pengambilan sampel dilakukan menggunakan metode sensus, yaitu seluruh populasi digunakan sebagai sumber data atau responden. Pemilihan metode ini dikarenakan jumlah populasi masih terbilang sedikit dan terpusat. 


\section{Data dan Instrumentasi}

Data penelitian terdiri dari data primer dan sekunder. Data primer adalah data yang diperoleh langsung dari responden yaitu fasilitator melalui kuesioner dan wawancara. Sedangkan data sekunder adalah data yang diperoleh dari hasil-hasil penelitian, kajian pustaka, peraturan perundang-undangan, datadata terkait dengan fasilitator dari P4TK Pertanian, dan data lain yang relevan dengan penelitian. Pengumpulan data dilakukan pada bulan April hingga Juli 2011.

Instrumen penelitian yang digunakan dalam penelitian ini adalah kuesioner yang berisi daftar pertanyaan yang berkaitan dengan peubah-peubah bebas (X) dan peubah tidak bebas (Y). Sebelum kuesioner digunakan, terlebih dahulu dilakukan ujicoba pada 30 orang responden fasilitator untuk mengetahui validitas dan reliabilitas instumen. Hasil uji realiabilitas menggunakan korelasi product moment pada Tabel 1 menunjukkan bahwa instrumen penelitian untuk responden fasilitator reliabel untuk semua peubah, oleh karena itu instrumen digunakan untuk pengumpulan data responden fasilitator tanpa ada perubahan item pertanyaannya.

\section{Analisis Data}

Analisis data dilakukan dalam dua tahap yaitu analisis statistik deskriptif dan inferensial. Analisis statistik deskriptif dilakukan untuk mendapatkan gambaran umum sebaran data setiap peubah penelitian yang diperoleh. Sedangkan analisis statistik inferensial dilakukan untuk menguji hipotesis penelitian dengan menggunakan SEM (Structural Equation Modex)

\section{Hasil dan Pembahasan}

\section{Karakteristik Fasilitator}

Karakteristik fasilitator merupakan bagian dari individu dan melekat pada diri seorang fasilitator yang mendasari tingkah laku sebagai fasilitator. Karakteristik fasilitator dalam penelitian ini diukur berdasarkan umur, pendidikan formal, pengalaman kerja, dan jabatan. Hasil pengukuran karakteristik fasilitator disajikan pada Tabel 2.

Umur fasilitator P4TK Pertanian berkisar antara 30 sampai dengan 55 tahun dengan rata-rata
45 tahun. Sebagian besar fasilitator berada dalam kategori senior yaitu umur $>44$ tahun, sebanyak 84 orang $(69,42 \%)$. Sedang-kan sisanya sebanyak 36 orang $(29,75 \%)$ berada pada kategori sedang yaitu umur $31-44$ tahun dan 1 orang $(0,83 \%)$ berumur muda yaitu 25-30 tahun. Pendidikan formal fasilitator P4TK Pertanian sebagian besar berpendidikan jenjang S2 yaitu sebanyak 80 orang $(66,12 \%)$, diikuti jenjang S1 sebanyak 40 orang $(33,06 \%)$, dan jenjang S3 sebanyak 1 orang $(0,83 \%)$.

Pengalaman kerja fasilitator sebagian besar sudah mencapai kategori tinggi yaitu di atas 10 tahun sebanyak 89 orang $(73,55 \%)$. Sedangkan sedangkan sisanya sebanyak 18 orang $(14,88 \%)$ berpengalaman kerja kategori sedang antara 6-10 tahun dan sebanyak 14 orang $(11,57 \%)$ berpengalaman kerja kategori rendah kurang dari 5 tahun. Pengalaman kerja terendah adalah 4 tahun dan tertinggi 29 tahun dengan rata-rata 16,7 tahun. Berdasarkan jabatan diketahui bahwa sebagian besar fasilitator memiliki jabatan tingkat madya dan pertama yaitu $43,80 \%$ dan $33,06 \%$, sedangkan sisanya $23,14 \%$ berada pada tingkat muda.

\section{Keterlibatan Fasilitator dalam Proses Belajar}

Keterlibatan fasilitator dalam proses belajar merupakan kegiatan belajar yang dilakukan untuk mendukung pengembangan kompetensi. Keterlibatan fasilitator dalam proses belajar diukur berdasarkan keikutsertaan dalam kegiatan pelatihan, partisipasi dalam kegiatan ilmiah, keikutsertaan magang industri, pelaksanaan unit produksi, dan pemanfaatan sumber belajar. Hasil pengukuran keterlibatan fasilitator dalam proses belajar disajikan pada Tabel 2 .

Keterlibatan fasilitator dalam proses belajar seperti pada Tabel 2 menunjukkan bahwa sebagian besar berada pada kategori sedang yaitu sebanyak $68,60 \%$ diikuti kategori rendah sebanyak 18,18\%, dan kategori tinggi sebanyak 13,22\%. Pada kelima sub peubah tersebut sebagian besar fasilitator berada pada kategori sedang, diikuti kategori tinggi dan rendah. Sub peubah mengikuti magang industri dan melaksanakan unit produksi tidak ada fasilitator yang berkategori rendah. Keikutsertaan fasilitator dalam mengikuti kegiatan pelatihan meliputi pelatihan bidang keahliannya, pelatihan manajemen, pelatihan kependidikan, pelatihan motivasi, dan pelatihan kepemimpinan. Pada sub peubah tersebut sebagian 
Tabel 1 Hasil Uji Reliabilitas Instrumen Penelitian Responden Fasilitator

\begin{tabular}{lcccc}
\hline \multicolumn{1}{c}{ Peubah } & $\begin{array}{c}\text { Jumlah } \\
\text { Item }\end{array}$ & Skala Ordinal & $\begin{array}{c}\text { Cronbach } \\
\text { Alfa }\end{array}$ & Keterangan \\
\hline Keterlibatan dalam proses belajar (X2) & 20 & $1-4$ & 0,710 & Reliabel \\
Lingkungan kerja fasilitator (X3) & 34 & $1-4$ & 0,895 & Reliabel \\
Motivasi fasilitator (X4) & 64 & $1-4$ & 0,971 & Reliabel \\
\hline Kompetensi fasilitator (Y1) & 80 & $1-4$ & 0,982 & Reliabel \\
\hline
\end{tabular}

besar fasilitator sebanyak 76,86\% berada pada kategori sedang, diikuti kategori tinggi dan rendah dengan jumlah yang sama sebanyak $11,57 \%$.

Berpartisipasi dalam kegiatan ilmiah merupakan keikutsertaan fasilitator dalam kegiatan seminar, workshop, ujicoba dan menulis karya ilmiah. Tingkat keterlibatan fasilitator pada kegiatan ilmiah tersebut sebagian besar berada pada kategori sedang, yaitu sebanyak $68,60 \%$, diikuti kategori tinggi sebanyak $17,36 \%$ dan kategori rendah sebanyak 14,05\%. Keikutsertaan fasilitator pada magang industri sebagian besar berada pada kategori sedang, yaitu 91,74\% diikuti kategori tinggi sebesar $8,26 \%$ dan tidak ada yang berkategori rendah. Magang adalah latihan kerja pada suatu instansi/industri tertentu dengan melakukan pekerjaan sesuai dengan jenis yang dipilih mengikuti sistem kerja pada instansi/ industri yang bersangkutan.

Unit produksi merupakan kegiatan produksi/ usaha suatu komoditas/produk tertentu yang dilakukan oleh fasilitator dalam skala komersial dibawah pengelolaan P4TK Pertanian sebagai wahana bagi fasilitator untuk mendapatkan pengalaman produksi secara komersial. Keterlibatan fasilitator dalam kegiatan unit produksi tersebut sebagian besar dalam kategori sedang, yaitu sebanyak 78,51\%, diikuti kategori tinggi sebanyak $21,49 \%$ dan tidak ada yang berkategori rendah. Keterlibatan dalam pemanfaatan sumberbelajar meliputiperpustakaan, internet, majalah/ buletin, koran/tabloid, dan buku literatur/ referensi sebagian besar fasilitator yaitu sebanyak 56,20\% berada pada kategori sedang dalam memanfaatkan sumber belajar, dan 23,97\% pada kategori tinggi serta $19,83 \%$ pada kategori rendah.

\section{Lingkungan Kerja Fasilitator}

Lingkungan kerja merupakan lingkungan fisik dan non-fisik di luar diri fasilitator yang mendukung atau mempengaruhi dirinya dalam mengembangkan kompetensi. Lingkungan kerja diukur berdasarkan sistem pemberian penghargaan, sistem evaluasi tugas pembelajaran, ketersediaan sarana/prasarana, sistem pengembangan karir, dan sistem pelak-sanaan kegiatan pelatihan. Hasil pengukuran lingkungan kerja disajikan pada Tabel 4. Lingkungan kerja fasilitator pada Tabel 4 menurut sebagian besar fasilitator yaitu sebanyak 68,60\% berada pada kategori sedang, selanjutnya $19,83 \%$ fasilitator menyatakan rendah dan $8,26 \%$ menyatakan kondisinya tinggi. Lingkungan kerja fasilitator meliputi pemberian penghargaan, sistem evaluasi, ketersediaan sarana dan prasarana, sistem pengembangan karir, dan sistem pelaksanaan kegiatan pelatihan.

Sub peubah sistem pemberian penghargaan berkaitan dengan tata cara pemberian kompensasi dalam bentuk materi dan non-materi. Kompensasi materi meliputi sistem pemberian honor mengajar dan besarnya honor mengajar yang diterima. Sedangkan kompensasi non-materi berupa sistem penerbitan surat tugas dan surat keterangan melaksanakan tugas. Kondisi sub peubah sistem pemberian penghargaan tersebut, sebagian besar fasilitator yaitu sebanyak 80,99\% menyatakan kondisinya sedang, $10,74 \%$ menyatakan kondisinya tinggi, dan $8,26 \%$ menyatakan kondisinya rendah.

Sub peubah sistem evaluasi pelaksanaan tugas pembelajaran berkaitan dengan penilaian kualitas mengajar fasilitator oleh peserta pelatihan meliputi pemberian hasil penilaian kepada fasilitator dan penggunaan hasil penilaian. Kondisi sistem evaluasi pelaksanaan tugas pembelajaran tersebut, sebagian besar fasilitator yaitu sebanyak $66,77 \%$ menyatakan sedang, $16,53 \%$ menyatakan tinggi dan $15,70 \%$ menyatakan rendah. Sub peubah ketersediaan sarana/prasarana berkaitan dengan kualitas dan kualitas sarana/prasarana pendukung pengembangan kompetensi fasilitator meliputi: (1) sarana/ prasarana pembelajaran teori yaitu ruang kelas, peralatan kelas (papan tulis, penghapus, spidol), media pembelajaran (tape recorder, televisi, LCD); (2) sarana/prasarana pembela-jaran praktik yaitu 
Tabel 2 Distribusi Fasilitator Berdasarkan Keterlibatan dalam Proses Belajar

\begin{tabular}{|c|c|c|c|}
\hline \multirow[b]{2}{*}{ Peubah/Sub Peubah } & \multirow[b]{2}{*}{ Kategori } & \multicolumn{2}{|c|}{ Jumlah } \\
\hline & & $\begin{array}{c}\text { Jml. } \\
\text { (orang) }\end{array}$ & $\begin{array}{c}\text { Persen } \\
(\%)\end{array}$ \\
\hline \multirow[t]{3}{*}{ Mengikuti pelatihan, X2.1 } & Rendah & 14 & 11,57 \\
\hline & Sedang & 93 & 76,86 \\
\hline & Tinggi & 14 & 11,57 \\
\hline \multirow[t]{3}{*}{ Berpartisipasi dalam kegiatan ilmiah, X2.2 } & Rendah & 17 & 14,05 \\
\hline & Sedang & 83 & 68,60 \\
\hline & Tinggi & 21 & 17,36 \\
\hline \multirow[t]{3}{*}{ Mengikuti magang industri, X2.3 } & Rendah & 0 & 0,00 \\
\hline & Sedang & 111 & 91,74 \\
\hline & Tinggi & 10 & 8,26 \\
\hline \multirow[t]{3}{*}{ Melaksanakan unit produksi, X2.4 } & Rendah & 0 & 0,00 \\
\hline & Sedang & 95 & 78,51 \\
\hline & Tinggi & 26 & 21,49 \\
\hline \multirow[t]{3}{*}{ Pemanfaatan sumber belajar, X2.5 } & Rendah & 24 & 19,83 \\
\hline & Sedang & 68 & 56,20 \\
\hline & Tinggi & 29 & 23,97 \\
\hline \multirow[t]{3}{*}{ Keterlibatan dalam proses belajar, X2 } & Rendah & 22 & 18,18 \\
\hline & Sedang & 83 & 68,60 \\
\hline & Tinggi & 16 & 13,22 \\
\hline
\end{tabular}

\begin{tabular}{ll}
\hline Keterangan: & Rendah $=<$ rata-rata- $\sigma ;$ \\
& Sedang $=$ rata-rata $\pm \sigma ;$ \\
& Tinggi $=>$ rata-rata $+\sigma$
\end{tabular}

ruang/tempat praktik (laboratorium, bengkel, bangsal, dapur, lahan, kolam, kandang), peralatan praktik; (3) bahan praktik; (4) ruang baca dan koleksi buku referensi dalam perpustakaan; (5) kondisi perpustakaan; (6) komputer; dan(7) jaringan internet. Kondisi ketersediaan sarana/prasarana tersebut, sebagian besar fasilitator yaitu sebanyak 80,99\% menyatakan sedang, 14,88\% menyatakan rendah dan hanya $4,13 \%$ yang menyatakan tinggi.

Sub peubah sistem pengembangan karir berkaitan dengan ketersediaan aturan dan peluang pengembangan karir bagi fasilitator. Kondisi sistem pengembangan karir tersebut, sebagian besar fasilitator yaitu sebanyak $68,60 \%$ menyatakan sedang, 16,53\% menyatakan rendah dan $14,88 \%$ menyatakan tinggi. Sub peubah sistem pelaksanaan kegiatan pelatihan berkaitan dengan persyaratan dan penugasan mengajar serta pelayanan kegiatan mengajar oleh penyelenggara pelatihan meliputi pemenuhan kebutuhan sarana/ prasarana, alat tulis kantor, dan bahan praktik. Kondisi sistem pelaksanaan kegiatan pelatihan tersebut, sebagian besar fasilitator yaitu sebanyak 77,69\% menyatakan sedang, $15,70 \%$ menyatakan rendah dan sebanyak $6,61 \%$ yang menyatakan tinggi.

\section{Motivasi Fasilitator}

Motivasi fasilitator merupakan faktor-faktor yang menggerakkan atau mendorong fasilitator untuk melaksanakan tugasnya. Motivasidiukurberadasarkan tiga komponen yaitu memperluas hubungan kerja, mengembangkan kemampuan bidang ilmu, dan melaksanakan tugas pembelajaran. Hasil pengukuran motivasi disajikan pada Tabel 5. Motivasi fasilitator pada Tabel 5 menunjukkan bahwa sebagian besar fasilitator yaitu sebanyak 57,85\% kategori sedang, se-lanjutnya $21,49 \%$ kategori rendah dan $20,66 \%$ kategori tinggi. Motivasi memperluas hubungan kerja sebagian besar fasilitator sebanyak $47,11 \%$ berada pada kategori sedang, lainnya sebanyak 28,10\% 
Tabel 5 Distribusi Fasilitator Berdasarkan Motivasi

\begin{tabular}{llcc}
\hline \multicolumn{1}{c}{ Peubah/Sub Peubah } & Kategori & \multicolumn{2}{c}{ Jumlah } \\
& & Jml (orang) & Persen (\%) \\
\hline Memperluas hubungan kerja, X4.1 & Rendah & 34 & 28,10 \\
& Sedang & 57 & 47,11 \\
Mengembangkan kemampuan bidang ilmu, X4.2 & Tinggi & 30 & 24,79 \\
& Rendah & 42 & 34,71 \\
Melaksanakan tugas pembelajaran, X4.3 & Sedang & 43 & 35,54 \\
& Tinggi & 36 & 29,75 \\
Motivasi Fasilitator, X4 & Rendah & 29 & 23,97 \\
& Sedang & 66 & 54,55 \\
& Tinggi & 26 & 21,49 \\
& Rendah & 26 & 21,49 \\
& Sedang & 70 & 57,85 \\
\hline
\end{tabular}

$\begin{array}{ll}\text { Keterangan: } & \text { Rendah }=<\text { rata-rata- } \sigma ; \\ & \text { Sedang }=\text { rata-rata } \pm \sigma ; \\ & \text { Tinggi }=>\text { rata-rata }+\sigma\end{array}$

kategori rendah, dan sebanyak 24,79\% kategori tinggi. Motivasi dalam mengembangkan kemampuan bidang ilmu antara kategori sedang dan rendah relatif sama yaitu masing-masing sebanyak $35,54 \%$, dan $34,71 \%$ sedangkan kategori tinggi sebanyak 29,75\%. Motivasi dalam melaksanakan tugas pembelajaran sebagian besar fasilitator sedang yaitu sebanyak $54,55 \%$, selanjutnya rendah sebanyak $23,97 \%$, dan tinggi sebanyak $21,49 \%$.

\section{Kompetensi Fasilitator}

Kompetensi fasilitator merupakan kemampuan bertindak dalam melaksanakan tugas dan tanggung jawabnya sebagai fasilitator untuk membantu peserta pelatihan menguasai kompetensi tertentu sesuai materi pelatihan. Kompetensi fasilitator diukur berdasarkan penguasaan substansi materi, perencanaan pembelajaran, pelaksanaan pembelajaran, evaluasi pembelajaran, dan kerjasama. Hasil pengukuran kompetensi fasilitator disajikan pada Tabel 6.

Secara umum kompetensi fasilitator sebagai rata-rata dari kelima sub kompetensi sebagian besar berada pada kategori sedang yaitu sebanyak 76,86\% diikuti kategori tinggi sebanyak 19,01\%, dan kategori rendah sebanyak 4,13\%. Pada semua sub kompetensi sebagian besar kompetensi fasilitator berada pada kategori sedang, dimana pada semua sub kompetensi, kategori sedang lebih banyak dari kategori tinggi dan rendah. Jumlah fasilitator berkategori tinggi terendah terdapat pada sub kompetensi pelaksanaan pembelajaran sebanyak $18,18 \%$ dan tertinggi pada sub kompetensi penguasaan substansi materi sebanyak $23,14 \%$. Jumlah fasilitator berkategori sedang terrendah terdapat pada sub kompetensi kerjasama sebanyak 39,67\% dan tertinggi pada sub kompetensi pelaksanaan pembelajaran sebanyak $78,51 \%$. Jumlah fasilitator berkategori sedang terrendah terdapat pada sub kompetensi kerjasama sebanyak 39,67\% dan tertinggi pada sub kompetensi pelaksanaan pembelajaran sebanyak 78,51\%. Fasilitator yang memiliki kompetensi kategori rendah yaitu terendah pada sub kompetensi penguasaan Substansi materi sebanyak $0,83 \%$ dan tertinggi pada sub kompetensi kerjasama sebanyak 34,71\%.

Kompetensi fasilitator pada sub kompetensi penguasaan substansi materi sebagian besar berada pada kategori sedang sebanyak $76,03 \%$ diikuti kategori tinggi sebanyak 23,14\%, dan kategori rendah sebanyak 0,83\%. Kompetensi Penguasaan Substansi Materi dimaksud adalah menguasai keilmuan dan keterampilan mempraktekkan sesuai dengan materi pelatihan yang diajarkan. Tingkat kompetensi Penguasaan Substansi Materi berkaitan dengan latar belakang pendidikan dan kesesuaian latar belakang pendidikan dengan materi yang diajarkan. 
Tabel 6 Sebaran Kompetensi Fasilitator Pelatihan

\begin{tabular}{llrr}
\hline \multirow{2}{*}{ Sub Peubah } & Kategori & \multicolumn{2}{c}{ Jumlah } \\
& & Jml (orang) & Persen (\%) \\
\hline Penguasaan substansi materi, Y1.1 & Rendah & 1 & 0,83 \\
& Sedang & 92 & 76,03 \\
Perencanaan pembelajaran, Y1.2 & Tinggi & 28 & 23,14 \\
& Rendah & 11 & 9,09 \\
Pelaksanaan pembelajaran, Y1.3 & Sedang & 84 & 69,42 \\
& Tinggi & 26 & 21,49 \\
Evaluasi pembelajaran, Y1.4 & Rendah & 4 & 3,31 \\
& Sedang & 95 & 78,51 \\
Kerjasama, Y1.5 & Tinggi & 22 & 18,18 \\
& Rendah & 3 & 2,48 \\
Kompetensi Fasilitator, Y1 & Sedang & 92 & 76,03 \\
& Tinggi & 26 & 21,49 \\
& Rendah & 42 & 34,71 \\
& Sedang & 48 & 39,67 \\
& Tinggi & 31 & 25,62 \\
& Rendah & 5 & 4,13 \\
& Sedang & 93 & 76,86 \\
& Tinggi & 23 & 19,01 \\
\hline
\end{tabular}

\begin{tabular}{ll}
\hline Keterangan: & Rendah $=<$ rata-rata- $\sigma ;$ \\
& Sedang $=$ rata-rata $\pm \sigma ;$ \\
& Tinggi $=>$ rata-rata $+\sigma$
\end{tabular}

Kompetensi fasilitator pada sub kompetensi perencanaan pembelajaran sebagian besar berada pada kategori sedang, yaitu sebesar $69,42 \%$, diikuti kategori tinggi sebanyak 21,49\%, dan kategori rendah sebanyak 9,09\%. Kompetensi di bidang perencanaan pembelajaran dimaksud adalah kemampuan dalam menyusun rencana pembelajaran, modul pembelajaran, evaluasi pembelajaran, dan bahan presentasi penyajian materi.

Kompetensi fasilitator pada sub kompetensi pelaksanaan pembelajaran sebagian besar berada pada kategori sedang, yaitu sebesar 78,51\%, diikuti kategori tinggi, sebanyak $18,18 \%$, dan kategori rendah sebanyak 3,31\%. Kompetensi pelaksanaan pembelajaran yang dimaksudadalahmampumenerapkanpembelajaranorang dewasa, mampu menggunakan metode pembelajaran, mampu melakukan komunikasi yang efektif dengan peserta, dan mampu memotivasi semangat belajar peserta didik.

Kompetensi fasilitator pada sub kompetensi evaluasi pembelajaran sebagian besar berada pada kategori sedang, yaitu sebanyak 76,03\%, diikuti kategori tinggi sebanyak 21,49\% dan kategori rendah sebanyak 2,48\%. Kompetensi pelaksanaan evaluasi pembelajaran dimaksud adalah mampu melaksanakan dan menganalisis hasil pre test, mampu melaksanakan dan menggunakan hasil post test, dan mampu melaksanakan penilaian hasil praktek.

Kompetensi fasilitator pada sub kompetensi kerjasama menunjukkan bahwa antara kategori rendah, redang, dan ringgi jumlahnya relatif sama meskipun pola urutannya sama dengan sub kompetensi lainnya yaitu terbanyak pada kategori sedang sebesar 39,67\%, diikuti kategori tinggi sebanyak 25,62\%, dan kategori rendah sebanyak $34,71 \%$.

\section{Faktor yang Berpengaruh terhadap Kompetensi Fasilitator}

Pengaruh peubah karakteristik fasilitator, keterlibatan fasilitator dalam proses belajar, lingkungan kerja fasilitator dan motivasi fasilitator terhadap kompetensi fasilitator dirumuskan berdasarkan uji SEM (Structural Equation Modex seperti Tabel 7. Tabel 7 
Jurnal Penyuluhan, September 2013 Vol. 9 No. 2

Tabel 7 Dekomposisi Efek Peubah Laten yang Berpengaruh terhadap Kompetensi Fasilitator

\begin{tabular}{llccc}
\hline \multicolumn{1}{c}{ Peubah Laten } & Pengaruh Total & Pengaruh Langsung & $\begin{array}{c}\text { Pengaruh Tidak } \\
\text { Langsung }\end{array}$ \\
\hline 1. & Karakteristik fasilitator & 0,15 & 0,15 & 0,00 \\
2. & Proses belajar dan motivasi & $0,32^{*}$ & $0,32^{*}$ & 0,00 \\
3. & Lingkungan kerja fasilitator & $0,15^{*}$ & $0,15^{*}$ & 0,00 \\
\hline
\end{tabular}

Keterangan:* signifikan pada $\mathrm{p}<0,05$

menunjukkan kompetensi secara langsung dipengaruhi oleh karakteristik fasilitator, keterlibatan fasilitator dalam proses belajar, motivasi fasilitator, dan lingkungan kerja dengan koefisien masing-masing: 0,$15 ; 0,32^{*}$, dan $0,15^{*}$. Pengaruh langsung keempat peubah tersebut berdasarkan uji t-test menunjukkan bahwa peubah yang berpengaruh nyata terhadap kompetensi fasilitator adalah keterlibatan fasilitator dalam proses belajar, motivasi fasilitator, dan lingkungan kerja fasilitator. Sedangkan peubah karakteristik fasilitator berpengaruh tidak nyata terhadap kompetensi fasilitator. Hasil tersebut menunjukkan bahwa kompetensi keterlibatan fasilitator dalam proses belajar, motivasi fasilitator, dan lingkungan kerja fasilitator berperan nyata dalam peningkatan kompetensi fasilitator. Peningkatan kondisi ketiga peubah tersebut akan mengakibatkan meningkatnya kompetensi fasilitator.

Karakteristik fasilitator berpengaruh positif tidak nyata pada kompetensi fasilitator dengan nilai koefisien pengaruh sebesar 0,15 . Hal tersebut berarti bahwa karakteristik fasilitator yang terdiri dari umur, pendidikan formal, pengalaman kerja, dan jabatan tidak valid digunakan untuk mengestimasi kompetensi fasilitator. Artinya, meningkatnya umur, pendidikan formal, pengalaman kerja, dan jabatan tidak secara nyata menyebabkan meningkatnya kompetensi fasilitator. Pendidikan formal fasilitator P4TK Pertanian berdasarkan jenjang pendidikannya terdapat sebanyak 39 orang $(32,23 \%)$ berpendidikan S1, 81 orang $(66,94 \%)$ berpendidikan S2, dan 1 orang $(0,83 \%)$ berpendidikan S3. Peningkatan jenjang pendidikan formal dari S1 ke S2 dan S3 tidak menunjukkan pengaruh nyata terhadap peningkatan kompetensi fasilitator. Hal tersebut berhubungan dengan perbedaan karakteristik pendidikan formal S2 dan S3 yang lebih bersifat akademik sedangkan kompetensi yang dibutuhkan fasilitator disamping akademik juga teknis. Perbedaan tuntutan kebutuhan kompetensi dan hasil yang diperoleh dari peningkatan pendidikan formal tersebut menyebabkan pendidikan formal berpengaruh tidak nyata terhadap kompetensi fasilitator karena peningkatan pendidikan formal tidak secara nyata memenuhi kebutuhan kompetensi fasilitator. Disamping pendidikan formal, peningkatan pengalaman kerja juga tidak memberikan pengaruh yang nyata terhadap kompetensi fasilitator. Pengalaman kerja fasilitator P4TK Pertanian berkisar antara 4 tahun sampai dengan 29 tahun, dengan rata-rata 16,7 tahun. Sebagian besar fasilitator, yaitu sebanyak 73,55\% memiliki pengalaman kerja $>10$ tahun. Pengalaman kerja yang relatif lama tersebut sudah memasuki tahap kejenuhan sehingga motivasi untuk meningkatkan kompetensi mulai menurun. Kondisi tersebut mengakibatkan rendahnya peningkatan kompetensi fasilitator sehingga pengalaman kerja tidak memberi pengaruh nyata terhadap peningkatan kompetensi fasilitator.

Keterlibatan fasilitator dalam proses belajar dan motivasi berpengaruh positif nyata terhadap kompetensi fasilitator dengan nilai koefisien pengaruh sebesar 0,32. Hal tersebut berarti bahwa keterlibatan dalam proses belajar dan motivasi valid digunakan untuk mengestimasi kompetensi fasilitator dimana setiap peningkatan satu satuan keterlibatan dalam proses belajar dan motivasi, akan meningkatkan kompetensi fasilitator sebesar 0,32 satuan. Indikator peubah keterlibatan dalam proses belajar dan motivasi yang mempengaruhi secara nyata kompetensi fasilitator adalah: (1) keterlibatan dalam proses belajar meliputi mengikuti pelatihan, berpartisipasi dalam kegiatan ilmiah, mengikuti magang industri, melaksanakan unit produksi, dan memanfaatkan sumber belajar; (2) motivasi fasilitator meliputi memperluas hubungan kerja, mengembangkan kemampuan bidang ilmu, dan melaksanakan tugas pembelajaran.

Keterlibatan fasilitator dalam proses belajar sebagian besar berada pada kategori sedang dan tinggi yaitu $81,82 \%$ dengan perincian kategori sedang $68,60 \%$ dan kategori tinggi $13,22 \%$. Secara keseluruhan selama 
tiga tahun terakhir semua fasilitator pernah mengikuti pelatihan, berpartisipasi dalam kegiatan ilmiah, mengikuti magang industri, melaksanakan unit produksi, dan memanfa-atkan sumber belajar dengan frekuensi yang berbeda-beda. Pemanfaatan sumber belajar yang terdiri dari pemanfaatan perpustakaan, internet, majalah/ buletin, koran/tabloid, dan buku literatur/referensi merupakan proses belajar paling banyak dilakukan oleh fasilitator jika dibandingkan dengan proses belajar lainnya. Hal tersebut terjadi karena fasilitator dapat melakukan secara mandiri pemanfaatan sumber belajar sesuai dengan kebutuhannya tanpa tergantung dari program P4TK Pertanian. Sedangkan proses belajar fasilitator melalui kegiatan pelatihan, kegiatan ilmiah, magang industri, dan unit produksi tergantung dari program yang disediakan oleh P4TK Pertanian. Melalui keterlibatan fasilitator dalam proses belajar tersebut fasilitator selalu mengikuti perkembangan terkini sesuai bidang ilmunya sehingga dapat menambah wawasan, pengetahuan dan keterampilan untuk mendukung dan meningkatkan kompetensinya. Motivasi fasilitator sebagian besar berada pada kategori sedang dan tinggi yaitu sebanyak 78,41\% dengan perincian kategori sedang sebanyak 57,85\% dan kategori tinggi sebanyak 20,66\%. Motivasi mengembangkan kemampuan bidang ilmu merupakan motivasi dengan jumlah kategori sedang dan tinggi paling rendah diikuti memperluas hubungan kerja dan melaksanakan tugas pembelajaran. Kondisi motivasi tersebut merupakan modal utama fasilitator untuk meningkatkan kompetensinya.

Lingkungan kerja fasilitator berpengaruh positif nyata terhadap kompetensi fasilitator dengan nilai koefisien pengaruh sebesar 0,15 . Hal tersebut berarti bahwa lingkungan kerja valid digunakan untuk mengestimasi kompetensi fasilitator dimana setiap peningkatan satu satuan lingkungan kerja, akan meningkatkan kompetensi fasilitator sebesar 0,15 satuan. Indikator peubah lingkungan kerja yang berpengaruh nyata terhadap kompetensi fasilitator adalah: (1) sistem pemberian penghargaan; (2) sistem evaluasi pelaksanaan tugas pembelajaran; (3) ketersediaan sarana dan prasarana; (4) sistem pengembangan karir; dan (5) sistem pelaksanaan kegiatan pelatihan. Kondisi lingkungan kerja fasilitator belum sepenuhnya dirasakan fasilitator mendukung pengembangan kompetensi. Sistem penghargaan sebagian besar fasilitator yaitu sebanyak $80,99 \%$ menyatakan kondisinya sedang, $10,74 \%$ menyatakan kondisinya tinggi, dan $8,26 \%$ menyatakan kondisinya rendah. Melalui wawancara terungkap bahwa pada umumnya fasilitator menyatakan belum puas dengan sistem penghonoran mengajar yang dijalankan sekarang. Jumlah honor yang diterima dirasakan belum memuaskan dan turunnya honor juga tidak terjadwal dengan baik. Penerbitan surat tugas dan surat keterangan melaksanakan tugas dirasakan belum teroganisasi dengan baik sehingga sering terlambat diterima fasilitator bahkan beberapa fasilitator menyatakan terpaksa membuat sendiri surat tugas dan surat keterangan melaksanakan tugas untuk kepentingan pengajuan angka kredit.

\section{Strategi Pengembangan Kompetensi Fasilitator}

Berdasarkan peta kompetensi fasilitator dan pengaruh peubah-peubah bebas terhadap kompetensi maka pengembangan kompetensi fasilitator P4TK Pertanian dilakukan melalui: (a) perbaikan lingkungan kerja diprioritaskan pada sistem pemberian penghargaan dengan melakukan penyesuaian sistem penghonoran sesuai harapan fasilitator dan perbaikan sistem penyelenggaraan pelatihan diprioritaskan pada peningkatan pelayanan internal berupa pemrosesan surat tugas dan surat keterangan melaksanakan tugas mengajar; (b) peningkatan keterlibatan fasilitator dalam proses belajar diprioritaskan pada peningkatan keikutsertaan fasilitator pada kegiatan pelatihan keterampilan pertanian, motivasi, manajemen dan kepemimpinan; (c) peningkatan kompetensi fasilitator diprioritaskan pada menyusun perencanaan pembelajaran dan melakukan kerjasama.

\section{Kesimpulan}

Fasilitator pada umumnya berumur antara 4160 tahun (dewasa madya), berpendidikan formal S2, berpengalaman sebagai fasilitator lebih dari 10 tahun dan mempunyai jabatan tingkat madya (IVa-c) dan pertama (IIIa-b). Keterlibatan fasilitator dalam proses belajar, lingkungan kerja dan motivasi sebagian besar fasilitator berada pada kategori sedang.

Kompetensi fasilitator sebagian besar berkategori sedang dimana pada sub kompetensi perencanaan pembelajaran dan kerjasama masih banyak fasilitator yang berkompetensi rendah. Faktor yang berpengaruh secara positif nyata terhadap kompetensi fasilitator adalah keterlibatan dalam proses belajar dan motivasi, dan lingkungan kerja. Faktor karakteristik fasilitator berpengaruh langsung 
dan positif tetapi tidak nyata.

Pengembangan kompetensi bagi para fasilitator diprioritaskan pada kompetensi menyusun perencanaan pembelajaran dan kerjasama yang dilakukan melalui peningkatan keterlibatan fasilitator dalam proses belajar, peningkatan motivasi menyusun perencanaan pembelajaran, dan peningkatan lingkungan kerja fasilitator yang mendukung proses belajar.

\section{Daftar Pustaka}

Boyatzis RE. 1982. The Competent Manager: A Model for Effective Performance. New York: John Wiley \& Sons.

Departemen Pendidikan Nasional. 2003. Sistem Pendidikan Nasional. Jakarta (ID): Depdiknas.

Malthis RL, Jackson JH. 2002. Manajemen Sumber Daya Manusia. Jakarta (ID): Salemba Empat.

Mangkunegara, PA. 2005. Evaluasi Kinerja SDM. Bandung (ID): Refika Aditama.

McClelland DC. 1973. Testing for Competence rather than for Intelligence. American Psycologist.

Moehariono. 2009. Pengukuran Kinerja Berbasis Kompetensi. Bogor (ID): Ghalia Indonesia.

Moekijat. 1990. Evaluasi Pelatihan dalam Rangka Meningkatkan Produktivitas Perusahaan. Bandung (ID): Penerbit Mandar Maju.

Roestiyah. 2001. Strategi Belajar Mengajar. Jakarta (ID): Rineka Cipta.

Spencer LM, Spencer SM. 1993. Competence at Work: Models for Superior Performance. New York: John Wiley \& Sons, Inc. 